\title{
PON1 Status and Neurologic Symptom Complexes in Gulf War Veterans
}

\author{
Clement E. Furlong ${ }^{1}$ \\ Departments of Genetics and Medicine, University of Washington, Seattle, Washington 98195-7360 USA
}

I a case of potential exposure to toxic chemicals, it is often difficult to dissect the genetic, physiological, and environmental factors that contribute to illness. A recently published paper (Haley et al. 1999) raises the possibility of a link between detoxication enzyme genotype/ phenotype and the risk of illness in Gulf War veterans. This work builds on a body of interesting data regarding detoxication enzyme polymorphisms and highlights the need to consider both genotypic and phenotypic information in epidemiological studies.

Haley et al. (1997) had previously identified six unique symptom complexes, which they suggested could represent neurologic syndromes or injury sustained in the Gulf War. In the present study (Haley et al. 1999), they examined the relationship of polymorphisms in the paraoxonase gene (PON1) to presentation of neurologic symptom complexes in Gulf War veterans. Paraoxonase (PON1) is a high density lipoprotein (HDL)-associated enzyme that metabolizes oxidized lipids and also hydrolyzes arylesters and a number of toxic organophosphorus (OP) compounds, including insecticides and nerve agents (Aldridge 1953b; Geldmacher-von Mallinckrodt and Diepgen 1988; Davies et al. 1996). Haley et al. (1999) found that veterans homozygous for a specific PON1 allele $\left(P O N 1_{\mathrm{Q} 192}\right)$ were less likely to have neurologic symptom complexes than those possessing the alternate allele $\left(P O N 1_{\mathrm{R} 192}\right)$. They also noted that low activity of the plasma PON1 $1_{\mathrm{Q} 192}$ isoform distinguished ill veterans from controls even better than the PON1 genotype. According to Haley et al. (1999), these results support

\footnotetext{
1 E-MAIL clem@u.washington.edu; FAX: (206) 543-0754.
}

the contention that Gulf War-related neurologic syndromes were caused by exposure to toxic chemical compounds.

Do their conclusions seem to be justified based on what is known about the human PON1 192 protein polymorphism? Ideally, in an OP exposure scenario, the parameters that would be useful for an epidemiological study are (1) an identification of the compounds to which the individual was exposed, (2) a measure of the level of exposure, (3) a determination of the consequence of the exposure (e.g., toxin-mediated depression of cholinesterase levels), and (4) the status of an individual's genetic factors that contribute to sensitivity or resistance to the specific compound(s) to which the individual was exposed. Unfortunately, for Gulf War exposures, it is difficult to assess the level of exposure to specific chemicals, and little, if any, information is available on cholinesterase levels before and after exposure.

Without the availability of exposure information and cholinesterase inhibition data, the authors have focused on measurable parameters: the status of two detoxifying enzyme systems in individuals with symptom complexes. One of these enzymes, butyrylcholinesterase (BChE), acts as a suicide trap for specific toxic OP compounds; that is, once $\mathrm{BChE}$ reacts with an OP molecule, the $\mathrm{OP}$ is not available for inhibiting cholinesterase, but the enzyme is inactivated in the process (Aldridge 1953a). The second enzyme, PON1, is capable of catalytically hydrolyzing a number of toxic organophosphates (Aldridge 1953b; Geldmacher-von Mallinckrodt and Diepgen 1988; Davies et al. 1996). PON1 is tightly associated with HDL ("good cholesterol") particles (Blatter et al. 1993), and its main physiological function appears to be the metabolism of oxidized lipids and prevention of vascular disease (Mackness et al. 1991, 1993; Watson et al. 1995). However, PON1 also hydrolyzes (inactivates) various toxic OP compounds including paraoxon, chlorpyrifos oxon, diazoxon, soman, and sarin (Davies et al. 1996). In human populations, PON1 exhibits a substrate-dependent polymorphism; that is, different substrates (OPs) are hydrolyzed at different rates by different isoforms of PON1. Two genetic polymorphisms known in human populations are the L55M substitution and the Q192R substitution (numbering from the initiator methionine that is the only amino acid removed during secretion of this protein from the liver cells into the serum).

Haley et al. (1999) noted that PON1 $1_{\mathrm{R} 192}$ homozygotes or $\mathrm{PON} 1_{\mathrm{Q} / \mathrm{R} 192}$ heterozygotes were more likely to have neurologic symptom complexes than were individuals homozygous for PON1 $1_{\mathrm{Q} 192}$. In addition, they measured the serum activity of the enzymes and noted that low activity of the plasma PON1 ${ }_{\mathrm{Q} 192}$ isoform correlated with illness better than the PON1 genotype or the activity levels of the PON1 $1_{\mathrm{R} 192}$ isoform, total arylesterase, total paraoxonase, or BCHE. Altogether, these results suggest that the $P O N 1_{Q 192}$ allele had a protective effect against neurologic symptom complexes in Gulf War veterans. Here, we will examine the available evidence as to whether it is reasonable that individuals with a specific PON1 status could be more sensitive to the effects of OP compounds than individuals with a different PON1 status, and why this might be so.

Historically, it was known that one enzyme isoform hydrolyzed paraoxon at a high rate and the other at a lower rate (Geldmacher-von Mallinckrodt and 
Diepgen 1988). Several years of research in two laboratories, our own and Dr. Bert La Du's (University of Michigan), showed that the amino acid arginine at position 192 resulted in a higher rate of hydrolysis for paraoxon, whereas glutamine at this position resulted in a slower rate of paraoxon hydrolysis. (Adkins et al. 1993; Humbert et al. 1993). The opposite is true for soman and sarin (Davies et al., 1996). Subsequent research has shown that there is an association of PON1 $1_{\text {M55 }}$ isoform with lower levels of PON1 activity in serum (Blatter Garin et al. 1997; Mackness et al. 1997), but this is not an absolute association. Some individuals homozygous for PON1 $1_{\mathrm{M} 55}$ have high PON1 levels and some homozygous for PON1 $1_{\mathrm{L} 55}$ have low PON1 levels, the opposite of what would be expected from statistical studies of populations (Furlong et al., 2000; Brophy, V.H., G.P. Jarvik, R.J. Richter, L.S. Rozek, G.D. Schellenberg, and C.E. Furlong, in prep).

In earlier studies, we developed PCR-based assays for determining PON1 genotypes (Humbert et al. 1993), as well as two-substrate activity assays that provided an accurate inference of the PON1 192 genotype. Plotting rates of diazoxon hydrolysis versus paraoxon hydrolysis for individuals in a population divided the population into three groups of individuals, individuals homozygous for PON1 $1_{\mathrm{Q} 192}$, heterozygotes, and individuals homozygous for PON1 $1_{\mathrm{R} 192}$ (Davies et al. 1996; Richter and Furlong 1999). In addition to providing an accurate inference of the PON1 192 genotype, the two-dimensional enzyme analysis also provides a measure of how much PON1 activity is present in an individual's serum (Davies et al. 1996; Richter and Furlong 1999). These assays are similar to those developed by $\mathrm{La} \mathrm{Du}$ and coworkers (Eckerson et al. 1983) using phenylacetate and paraoxon as the substrate pair.

Because PON1 levels vary among individuals by at least 13-fold (Furlong et al. 1989; Davies et al. 1996), it is as important to consider PON1 levels as PON1 192 genotypes in epidemiological studies (Richter and Furlong 1999). A number of studies have been carried out attempting to relate the PON1 genotype with cardiovascular disease (for review, see Navab et al. 1996; Heinecke and Lusis 1998; Mackness et al. 1998). Unfortunately, virtually all of these studies have ignored the variability of PON1 levels between individuals and have considered only the PON1 192 genotype (Richter and Furlong 1999). The study by Haley et al. (1999) is therefore one of the first to examine the effects of both genotype and phenotype on possible environmental exposures.

However, an important question to ask is "Do differences in rates of hydrolysis of substrates measured in vitro actually reflect differences in sensitivity of an individual to specific OP compounds?" The pathways for OP detoxi-

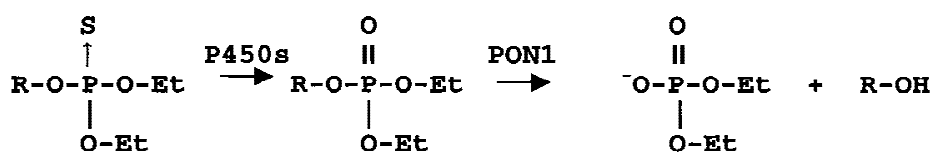

P450/PON1 Bioactivation and inactivation of an organophosphorothioate insecticide

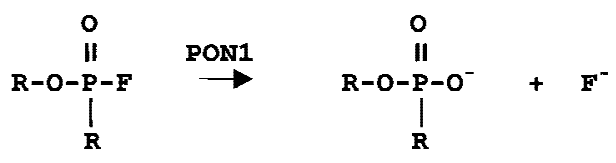

PON1 inactivation of a typical nerve agent

Figure 1 Pathways of OP detoxication. For the insecticides, a bioactivation reaction carried out by cytochrome P-450 (mixed function oxidases) is required to generate the very toxic oxon forms that inactivate the cholinesterases (Murphy 1980). The nerve agents do not require bioactivation for cholinesterase inhibition. cation are shown in Figure 1. Early evidence showed a good correlation between PON1 levels in different species and their resistance to specific OP compounds (Brealey et al. 1980; Costa et al. 1987; Furlong et al. 1989). More direct tests of this hypothesis involved injecting purified rabbit PON1 into rodents and demonstrating increased resistance to specific OP compounds (Main 1956; Costa et al. 1990; Li et al. 1993, 1995). These experiments clearly demonstrated that high levels of PON1 protected against cholinesterase inhibition by exposure to the highly toxic oxon forms of parathion or chlorpyrifos. The injected enzyme also provided some protection against dermal exposure to the parent compound chlorpyrifos in mice (Li et al. 1993, 1995).

What about the consequence of having low PON1 levels? Recent experiments with PON1 knockout mice generated by Dr. Jake Lusis (UCLA) and coworkers clearly demonstrated that low PON1 levels resulted in a dramatic increase in sensitivity to chlorpyrifos oxon (Shih et al. 1998) and diazoxon (Furlong et al.). The availability of PON1 knockout mice has provided a very informative model system for examining sensitivity to these toxins. It should be noted that the mutation that knocked out serum PON1 also knocked out liver PON1, leaving the mice totally devoid of PON1 contribution to OP detoxication (Furlong et al.). Surprisingly, the knockout mice did not demonstrate an increased sensitivity to paraoxon, the substrate for which PON1 was named.

Thus, the in vivo evidence available to date indicates that low PON1 levels can result in increased sensitivity to specific OP compounds. The surprising observation that PON1 knockout mice are not more sensitive to paraoxon points out the need to carry out exposure experiments in an appropriate in vivo model system. Because in vitro assays have shown that the PON1 $1_{\mathrm{R} 192}$ isoform does not hydrolyze sarin, or hydrolyzes it very slowly, it will also be important to determine whether human $\mathrm{PON} 1_{\mathrm{Q} 192}$ can provide in vivo protection against a sarin exposure.

In summary, while the studies re- 
ported by Haley et al. (1999) were carried out with a small number of subjects, their conclusions are interesting. Gulf War veterans were exposed to some compounds for which PON1 status (PON1 192 genotype/phenotype) contributes to resistance, consistent with the genetic and pharmacological data on the PON1 192 polymorphism. However, in a retrospective study of toxic exposures, it is difficult to determine the compounds to which individuals were exposed, as well as the level of exposure and the consequence of the exposure. Because an individual's PON1 status is stable over time, this parameter that can be reliably determined at later times.

In future OP poisoning cases, it will be important to encourage treating physicians to obtain cholinesterase values and to save frozen urine for analysis of metabolites to use in later identification of toxicants and determination of levels of exposure. Where it is not feasible to obtain cholinesterase values in suspected OP poisoning cases, it will still be worthwhile to preserve frozen urine samples for later analysis.

\section{REFERENCES}

Adkins, S., K.N. Gan M., Mody, and B.N. La Du. 1993. Am. J. Hum. Genet. 52: 599-568.
Aldridge, W.N. 1953a. Biochem. J. 53: 110-117. -. 1953b. Biochem. J. 53: 117-124.

Blatter, M.C., R.W. James, S. Messmer, F. Barja, and D. Pometta. 1993. Eur. J. Biochem. 211: 871-879.

Blatter Garin, M.C., R.W. James, P. Dussoix, H. Blanche, P. Rassa, P. Froguel, and J. Ruiz. 1997. J. Clin. Invest. 99: 62-66.

Brealey, C.J., C.H. Walker, and B.C. Baldwin. 1980. Pestic. Sci. 11: 546-554.

Costa, L.G., R.J. Richter, S.D. Murphy, G.S. Omenn, A.G. Motulsky, and C.E. Furlong. 1987. In Toxicology of pesticides: Experimental, clinical, and regulatory Perspectives (ed. L.G. Costa et al.), pp. 263-266. Springer-Verlag, Heidelberg, Germany.

Costa, L.G., B.E. McDonald, S.D. Murphy, G.S. Omenn, R.J. Richter, A.G. Motulsky, and C.E. Furlong. 1990. Toxicol. Appl. Pharmacol. 103: $66-76$.

Davies, H.G., R.J. Richter, M. Keifer, C.A. Broomfield, J. Sowalla, and C.E. Furlong. 1996. Nat. Genet. 14: 334-336.

Eckerson, H.W., C.M., Wyte, and B.N. La Du. 1983. Am. J. Hum. Genet. 35: 11261138.

Furlong, C.E., R.J. Richter, S.L. Seidel, L.G. Costa, and A.G. Motulsky. 1989. Anal. Biochem. 180: $242-247$

Furlong, C.E., W.-F. Li, V.H. Brophy, G.P. Jarvik, R.J. Richter, D.M. Shih, A.J. Lusis, and L.G. Costa. 2000. NeuroToxicology

Geldmacher-von Mallinckrodt, M., and T.L. Diepgen. 1988 Toxicol. Environ. Chem. 18: $79-196$

Haley, R.W., T.M. Kurt, and J. Hom. 1997. J. Am. Med. Assoc. 277: 215-222.

Haley, R.W., S. Billecke, and B. La Du. 1999. Toxicol. Appl. Pharmacol. 157: 227-233.

Hassett, C., R.J. Richter, R. Humbert, C. Chapline, J.W. Crabb, C.J. Omiecinski, and C.E. Furlong. 1991. Biochemistry 30: 10141-10149.
Heinecke, J.W. and A.J. Lusis. 1998. Am. J. Hum Genet.62: 20-24

Humbert, R., D.A. Adler, C.M. Disteche, C. Hassett, C.J. Omiecinski, and C.E. Furlong. 1993. Nat. Genet. 3: 73-76.

Li, W.-F., L.G. Costa, and C.E. Furlong. 1993. J. Toxicol. Environ. Health 40: 337346.

Li, W.-F., C.E. Furlong, L.G. Costa. 1995. Toxicol. Lett. 76: 219-226.

Mackness, M.I., S. Arrol, and P.N. Durrington. 1991. FEBS Lett. 286: 152-154.

Mackness, M.I., S. Arrol, C. Abbott, P.N. Durrington. 1993. Atherosclerosis 104: 129-135.

Mackness, B., I. Michael, S.A. Mackness, W. Turkie, P.N. Durrington. 1997. Br. J. Pharmacol. 122: $265-268$

Mackness, B., P.N. Durrington, and M.I. Mackness. 1998. Gen. Pharmacol.31: 329_ 336.

Main, A.R. 1956. Can. J. Biochem. Physiol. 34: $197-216$.

Murphy, S.D. 1980. In Toxicology: The basic science of poisons, 2nd ed. (ed. J. Doull et al.), pp. 357-408. Macmillan Publishing Co., New York, NY.

Shih, D.M., L. Gu, Y.R. Xia, M. Navab, W.-F. Li, S. Hama, L.W. Castellani, C.E. Furlong, L.G. Costa, A.M. Fogelman, A.J. Lusis. 1998. Nature 394: 284-287.

Navab, M. J.A. Berliner, A.D. Watson, S.Y. Hama, M.C. Territo, A.J. Lusis, D.M. Shih, B.J. Van Lenten, J.S. Frank, L.L. Demer, P.A. Edwards, and A.M. Fogelman. 1996. Aterioscler. Thromb. Vasc. Biol.16: 831-842

Richter, R.J. and C.E. Furlong, 1999. Pharmacogenetics 9: 745-753.

Watson A.D., J.A. Berliner, S.Y. Hama, B.N. La Du, K.F. Faull, A.F. Fogelman, M Navab. 1995. J. Clin. Invest. 96: 28822891.
Genome Research www.genome.org 


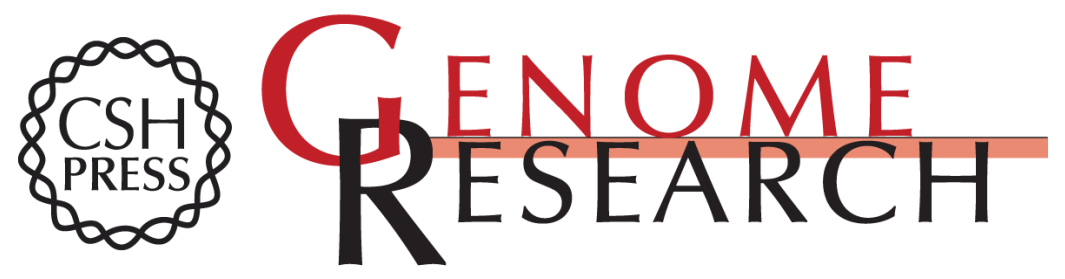

\section{PON1 Status and Neurologic Symptom Complexes in Gulf War Veterans}

Clement E. Furlong

Genome Res. 2000 10: 153-155

Access the most recent version at doi:10.1101/gr.10.2.153

References This article cites 24 articles, 3 of which can be accessed free at:

http://genome.cshlp.org/content/10/2/153.full.html\#ref-list-1

\section{License}

Email Alerting Receive free email alerts when new articles cite this article - sign up in the box at the Service top right corner of the article or click here.

\section{Affordable, Accurate Sequencing.}

